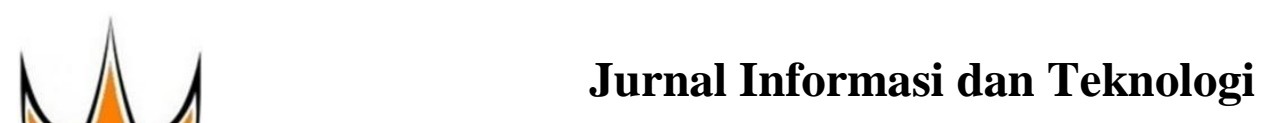

http://www.jidt.org

2021 Vol. 3 No. $4 \quad$ Hal: 202-208

e-ISSN: 2714-9730

\title{
Machine Learning Rekomendasi Produk dalam Penjualan Menggunakan Metode Item-Based Collaborative Filtering
}

\author{
Daniel Theodorus ${ }^{1 凶}$, Sarjon Defit ${ }^{2}$, Gunadi Widi Nurchayo ${ }^{3}$ \\ ${ }^{1}$ Sentral Tukang Indonesia \\ ${ }^{2,3}$ Universitas Putra Indonesia YPTK Padang \\ dtheo0690@gmai1 .com
}

\begin{abstract}
The shift towards Industry 4.0 has pushed many companies to adopt a digital system. With the sheer amount of data available today, companies start to face difficulties with providing product recommendation to their customers. As a result, data analysis has become increasingly important in the pursuit of providing the best service (user experience) to customers. The location appointed in this research is PT. Sentral Tukang Indonesia which is engaged in the sale of building materials and carpentry tools such as: paint, plywood, aluminum, ceramics, and hpl. Machine Learning has emerged as a possible solution in the field of data analysis. The recommendation system emerged as a solution in providing product recommendation based on interactions between customers in historical sales data. The purpose of this study is to assist companies in providing product recommendation to increase sales, to make it easier for customers to find the products they need, providing the best service (user experience) to customers. The data used is customer, item, and historical sales at PT. Sentral Tukang Indonesia over a time span of 1 period.data historical sales divide to dataset training $80 \%$ and dataset testing $20 \%$. The Item-based Collaborative Filtering method used in this study uses Cosine Similarity algorithm to calculate the level of similarity between products. Score prediction uses Weighted Sum formula while computation of error rate uses the Root Mean Squared Error formula. The result of this study shows top 10 product recommendations per customer. The products displayed are products with the highest score from the individual customer. This research can be used as a reference by companies looking to provide product recommendations needed by their customers.
\end{abstract}

Keywords: Machine Learning, Item-based Collaborative Filtering, Cosine Similarity, Recommendation System, Sentral Tukang Indonesia.

\begin{abstract}
Abstrak
Industri 4.0 mendorong banyak perusahaan bertransformasi ke sistem digital. Machine Learning merupakan salah satu solusi dalam analisa data. Analisa data menjadi poin penting dalam memberikan layanan yang terbaik (user experience) kepada pelanggan. Lokasi yang diangkat dalam penelitian ini adalah PT. Sentral Tukang Indonesia yang bergerak dalam bidang penjualan bahan bangunan dan alat pertukangan seperti: cat, tripleks, aluminium, keramik, dan hpl. Dengan banyaknya data yang tersedia, menyebabkan perusahaan mengalami kesulitan dalam memberikan rekomendasi produk kepada pelanggan. Sistem rekomendasi muncul sebagai solusi dalam memberikan rekomendasi produk, berdasarkan interaksi antara pelanggan dengan pelanggan lainnya yang terdapat di dalam data histori penjualan. Tujuan dari penelitian ini adalah Membantu perusahaan dalam memberikan rekomendasi produk sehingga dapat meningkatkan penjualan, memudahkan pelanggan untuk menemukan produk yang dibutuhkan, dan meningkatkan layanan yang terbaik kepada pelanggan.Data yang digunakan adalah data histori penjualan dalam 1 periode (Q1 2021), data pelanggan, dan data produk pada PT. Sentral Tukang Indonesia. Data histori penjualan tersebut akan dibagi menjadi $80 \%$ untuk dataset training dan $20 \%$ untuk dataset testing. Metode Item-based Collaborative Filtering pada penelitian ini memakai algoritma Cosine Similarity untuk menghitung tingkat kemiripan antar produk. Prediksi score memakai rumus Weighted Sum dan dalam menghitung tingkat error memakai rumus Root Mean Squared Error. Hasil dari penelitian ini memperlihatkan rekomendasi top 10 produk per pelanggan. Produk yang tampil merupakan produk yang memiliki score tertinggi dari pelanggan tersebut. Penelitian ini dapat menjadi referensi dan acuan bagi perusahaan dalam memberikan rekomendasi produk yang dibutuhkan oleh pelanggan.
\end{abstract}

Kata kunci: Machine Learning, Item-based Collaborative Filtering, Cosine Similarity, Sistem Rekomendasi, Sentral Tukang Indonesia.

() 2021 JIdT

\section{Pendahuluan}

PT. Sentral Tukang Indonesia merupakan salah satu toko retail yang bergerak dalam distribusi bahan bangunan. Memiliki cabang di kota Padang dan Pekanbaru. Banyaknya data pelanggan, produk dan data histori penjualan merupakan tantangan tersendiri pada perusahaan tersebut dalam memanfaatkan data. Data tersebut belum dimanfaatkan secara maksimal dalam menunjang pengambilan keputusan perusahaan.
Pergantian karyawan terutama bagian sales - admin menjadi salah satu permasalahan yang ada pada perusahaan tersebut sehingga menimbulkan masalah dalam memberikan pelayanan kepada pelanggan.

Knowledge Discovery in Database (KDD) merupakan sebuah proses dalam melihat suatu hubungan, pola baru dalam suatu data ataupun database yang besar dengan menggunakan pola statistik dan matematika [1]. Data Mining adalah bagian dalam proses dari KDD. Data 
Mining merupakan penemuan data dalam basis data Peneliti membangun sistem rekomendasi berbasis yang besar menggunakan pola statistik, matematik dan Machine Learning dengan menggunakan metode ItemMachine Learning dalam mengambil sebuah based Collaborative Filtering dengan memakai kesimpulan dari basis data yang akan diproses. Pada algoritma Cosine Similarity dalam menghitung masa sekarang, Machine Learning memakai rumus kemiripan produk menggunakan histori data penjualan. statistika dan aljabar linier.

Salah satu penerapan Machine Learning ini adalah dalam sistem rekomendasi [2]. Metode sistem Rekomendasi dapat dikelompokkan menjadi 2 bagian yaitu: metode Based On Content dan metode Collaborative Filtering. Metode Collaborative Filtering dibagi menjadi 2 macam yaitu metode Userbased Collaborative Filtering dan metode Item-based Collaborative Filtering.

Tujuan dari penelitian ini agar pelanggan mendapatkan rekomendasi barang yang dibutuhkan sewaktu akan melakukan order sehingga dapat meningkatkan pengalaman(user experience) yang baik.

\section{Metodologi Penelitian}

Pada metodologi penelitian ini terdapat langkahlangkah yang dilakukan untuk menyelesaikan permasalahan yang terjadi yang berhubungan dalam sistem rekomendasi menggunakan metode Item-Based Sistem rekomendasi menggunakan metode Based Collaborative Filtering. Kerangka kerja penelitian ini Collaborative Filtering digunakan dalam bidang yang digambarkan pada Gambar 1. pariwisata. Pariwisata di Kota Malang menghasilkan nilai prediksi menunjukkan kemiripan dengan pelanggan yang lain [3]. Sistem rekomendasi agenda wisata berbasis Android di Kota Bengkulu berdasarkan preferensi dari pengguna sebelumnya [4].

Implementasi sistem rekomendasi dengan menggunakan metode Based Collaborative Filtering dapat digunakan di bidang lain. Penelitian menggunakan analisa sentimen dalam pencarian hotel berdasarkan popularitas. Menghasilkan rekomendasi berkualitas tinggi dan mengurangi waktu dalam eksekusi sistem [5]. Dalam pemilihan kosentrasi mata kuliah dengan memakai data nilai mahasiswa dan data mata kuliah [6]. Rekomendasi produk kepada calon pembeli aksesoris smartphone berdasarkan rating dari setiap produk [7]. Sistem rekomendasi berbasis Machine Learning dalam memberikan rekomendasi musik berdasarkan preferensi pengguna menghasilkan tingkat kemiripan hingga 0,6684 , serta nilai precision mencapai 0,125 , nilai recall 0,200 , waktu response mencapai 3,5 detik [8].

Penelitian membahas mengenai improvisasi Collaborative Filtering. Item yang tidak memiliki nilai dari pengguna, maka sistem rekomendasi dapat memakai top-N items sebagai hasil rekomendasi [9]. Penelitian mengungkapkan bahwa pendekatan dengan memakai peringkat multi kriteria lebih baik daripada tradisional Item-based Collaborative Filtering [10]. Sistem rekomendasi dapat diterapkan dalam rekomendasi peringkat buku. Semakin besar jumlah pengguna, maka semakin tinggi indeks dan akan muncul paling atas memakai algoritma Jaccard Similarity [11]. Perbandingan antara tradisional Collaborative Filtering menunjukkan bahwa algoritma yang dilakukan Machine Learning menghabiskan waktu yang lebih sedikit dan dapat diandalkan [12]. Algoritma dengan memakai Item-based Collaborative Filtering lebih dapat menangani mode pembelajaran mooc saat ini dan memberikan layanan rekomendasi lebih baik dalam pembelajaran mooc. Algoritma sistem rekomendasi mencapai hasil yang bagus [13].

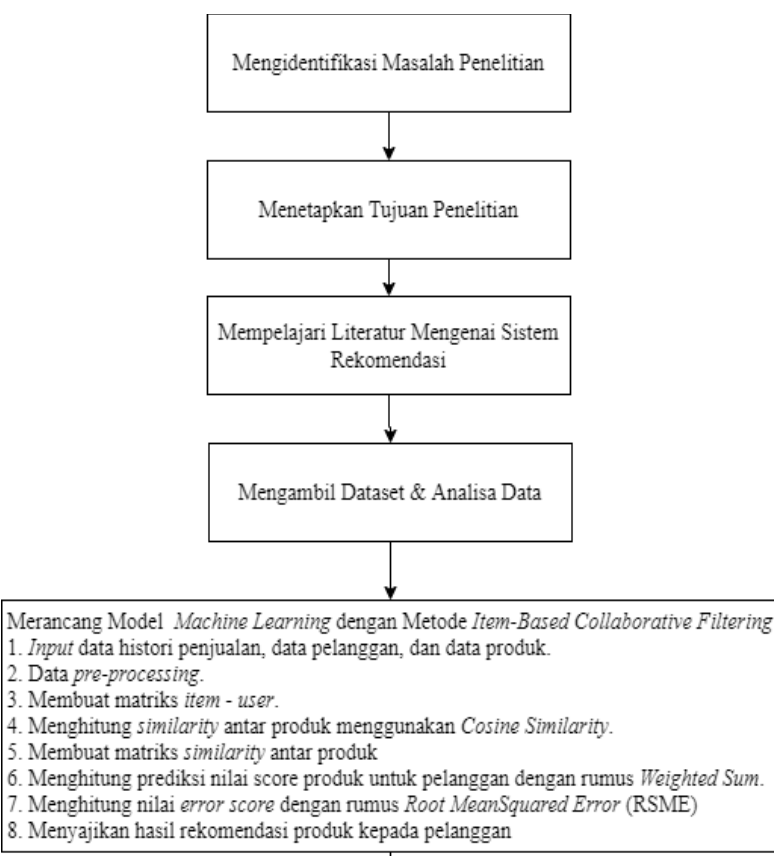

8. Menyajikan hasil rekomendasi produk kepada pelanggan

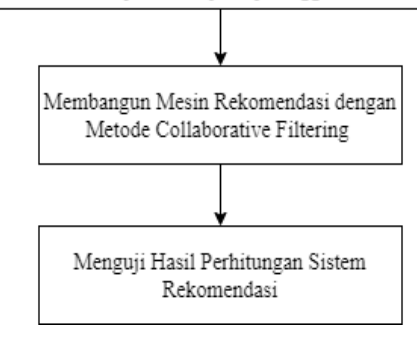

Gambar 1. Kerangka Kerja Penelitian

Berdasarkan kerangka kerja penelitian di atas, maka dapat diuraikan sebagai berikut:

a. Mengidentifikasi Masalah Penelitian.

Permasalahan yang terjadi adalah sales admin yang ada di PT. Sentral Tukang Indonesia sering mengalami pergantian, sehingga dalam memberikan rekomendasi produk kepada pelanggan tidak efektif, karena belum ada ketentuan yang baku dalam mengatur sistem rekomendasi ini.

Jurnal Informasi dan Teknologi Vol . 3 No. 4 (2021) 202-208 
b. Menetapkan Tujuan Penelitian.

Tujuan penelitian ini adalah untuk memberikan rekomendasi produk kepada pelanggan berdasarkan histori data penjualan.

c. Mempelajari Literatur Mengenai Sistem Rekomendasi.

Literatur yang dipakai berasal dari artikel, jurnal dan buku yang membahas mengenai sistem rekomendasi ini.

d. Mengambil Dataset \& Analisa Data.

Peneliti melakukan pengamatan langsung pada perusahaan tersebut. Selain itu, peneliti juga melakukan analisa terhadap data yang digunakan dalam penelitian ini. Peneliti memperoleh data Sistem rekomendasi merupakan sebuah sistem dan produk, data pelanggan, dan data histori penjualan teknik dalam memberikan saran baik berupa produk pada PT. Sentral Tukang Indonesia cabang yang kemungkinan besar disukai / menarik bagi Pekanbaru selama periode Q1 2021.

e. Merancang Model Machine Learning dengan Metode Item-based Collaborative Filtering.

Tahapan merancang model dilakukan dengan melihat konfigurasi kerangka kerja yang tersusun atas desain masukkan, alur proses metode Itembased Collaborative Filtering, desain hasil atau keluaran.

f. Membangun Sistem Rekomendasi dengan Metode Item-based Collaborative Filtering.

Tahapan ini dataset training dan testing terbagi atas 80\%-20\%. Pembagian dataset tersebut dilakukan secara random. Model yang dibangun berbasis Machine Learning dengan menggunakan PythonJupyter Notebook.

g. Menguji Hasil Perhitungan Sistem Rekomendasi.

Pada Tahapan ini menghasilkan hasil rekomendasi berupa top 10 produk yang memiliki score tertinggi per pelanggan.Tahapan ini dilakukan testing untuk menganalisis hasil perhitungan yang dilakukan dengan sistem rekomendasi metode Item-based Collaborative Filtering dengan Cosine Similarity.

\subsection{Machine Learning}

Machine Learning merupakan suatu teknik dalam melakukan inferensi terhadap data dengan memakai pendekatan secara matematis. Poin utama Machine Learning yaitu dalam pembuatan suatu model (matematis) yang mereferensikan pola-pola data. Machine Learning banyak memanfaatkan statistika dan aljabar linear [2]. Dataset terdiri Machine Learning dari dataset training dan dataset testing. Dataset training digunakan dalam mencari model yang cocok dalam melatih algoritma, sementara dataset testing akan dipakai untuk evaluasi dari kinerja dari model yang didapat [14]. Kegunaan dari Machine Learning sebagai berikut [15]: a. Classification adalah metode yang terdapat dalam Machine Learning yang dipakai untuk memprediksi suatu nilai/kelas dari individu dalam sebuah populasi.

b. Similarity matching adalah metode yang terdapat dalam Machine Learning yang digunakan untuk mengidentifikasi kemiripan antar individu berdasarkan data yang ada.

c. Clustering adalah metode yang terdapat dalam Machine Learning yang digunakan untuk membagi data - data ke dalam kelompok yang berdasarkan kriteria.

\subsection{Sistem Rekomendasi} pengguna tertentu. Sistem rekomendasi diharapkan dapat membantu pengguna dalam mengambil sebuah keputusan, seperti rekomendasi daftar lagu yang diprediksi untuk didengarkan oleh user [8]. Secara umum terdapat dua teknik dalam sistem rekomendasi yaitu: Content-based Filtering dan Collaborative Filtering. Content-based Filtering berfokus pada karakteristik pengguna secara spesifik. Collaborative Filtering berfokus pada selera terhadap suatu produk berdasarkan opini dari orang lain [16].

Dalam Item-based Collaborative Filtering, preferensi pelanggan dapat dikumpulkan dengan dua cara. Pertama, secara explicit dengan memakai perhitungan peringkat untuk produk dalam skala tertentu. Kedua, secara implicit demgan memakai data histori pembelian pengguna. Rekomendasi memakai User-based Collaborative Filtering menunjukkan hasil yang relatif lebih akurat, sedangkan rekomendasi dengan Itembased Collaborative Filtering memperlihatkan hasil yang relatif lebih stabil [17].

Cosine Similarity merupakan suatu teknik dalam mengukur kesamaan antara dua vektor dalam suatu produk [18]. Rumus Cosine Similarity dapat dilihat pada Persamaan 1.

$$
\operatorname{sim}(c, d)=\frac{C . D}{|C| \cdot|D|}=\frac{\sum_{i=1}^{n} C_{i} D_{i}}{\sqrt{\sum_{i=1}^{n} C_{i}^{2}} \sqrt{\sum_{i=1}^{n} D_{i}^{2}}}
$$

Dimana $\operatorname{sim}(\mathrm{c}, \mathrm{d})$ merupakan tingkat kesamaan vektor $\mathrm{C}$ dan vektor $\mathrm{D}, C_{i}$ dan $D_{i}$ merupakan komponen dari vektor $\mathrm{C}$ dan $\mathrm{D}$.

Weighted Sum merupakan penjumlahan dari perkalian rating atribut dengan bobot atribut. Untuk menghitung prediksi score dari produk - produk tersebut dengan membandingkan rating / nilai penjualan dari produk dengan kemiripan antara produk tersebut dengan produk lainnya. Rumus 
Weighted Sum dapat dilihat pada Persamaan 2 3.2. Membuat Matriks Item - User

[3][4].

$S_{(C, D)}=\frac{\sum i \in I\left(N_{C, i} * S_{i, D}\right)}{\sum i \in I\left|S_{i, D}\right|}$

Dimana $\mathrm{S}_{(\mathrm{C}, \mathrm{D})}$ merupakan prediksi nilai score produk D oleh pelanggan $\mathrm{C}, \quad \mathrm{i} \in$ Imerupakan himpunan produk, $N_{C, i}$ merupakan nilai penjualan pelanggan $\mathrm{C}$ pada penjualan i, $S_{i, D}$ merupakan nilai kemiripan produk i dan produk D.

Root Mean Squared Error merupakan suatu metode pengukuran dimana mengukur perbedaan nilai dari prediksi sebuah model sebagai estimasi / nilai yang diamati. Semakin kecil nilai RSME, maka akan semakin baik rekomendasi yang dihasilkan. Nilai RSME menggunakan rumus dalam Persamaan 3.

nilai_me $=\sqrt{\frac{\sum_{i=1}^{\mathrm{N}}\left(\mathrm{C}_{\mathrm{i}}-\widehat{\mathrm{C}_{1}}\right)^{2}}{\mathrm{~N}}}$

Dimana nilai_me merupakan nilai error, $C_{i}$ merupakan nilai aktual, $\widehat{C}_{l}$ merupakan nilai hasil peramalan, $\mathrm{N}$ merupakan nilai banyak data.

\section{Hasil dan Pembahasan} Pada tahap pembahasan ini menggunakan data histori
penjualan pada PT Sentral Tukang Indonesia cabang Pekanbaru periode Q1 2021. Berikut proses metode Item-based Collaborative Filtering yang dijelaskan dalam Gambar 2.

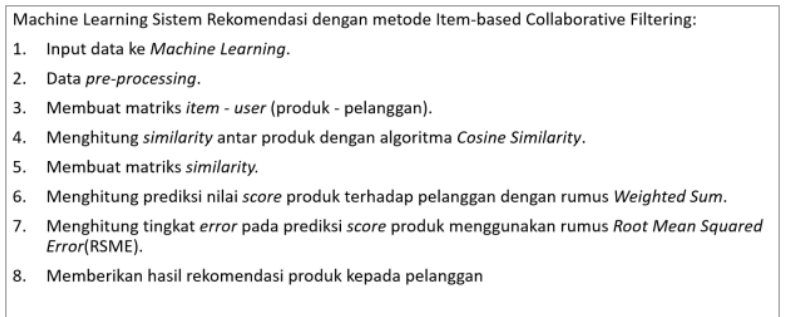

Gambar 2. Langkah - langkah Item-based Collaborative Filtering

\subsection{Input Data \& Data pre-processing}

Data histori penjualan akan dikelompokkan berdasarkan customer_no dan item_no, kemudian dihitung data per baris. Hal ini bertujuan agar rentang qty tidak terlalu besar. Data - data tersebut akan dibersihkan terlebih dahulu agar tidak ada data yang bernilai kosong, NULL, maupun duplikat.

Data yang diinput dan diolah adalah data training dan data testing. Data - data tersebut akan disusun berdasarkan kebutuhan sistem. Sistem rekomendasi membutuhkan 2 komponen utama yaitu item dan user. Komponen user dalam data tersebut adalah kolom $\sqrt{1+1+4+4+4+0}=\sqrt{14}=3,74165$ customer_no. Komponen item dalam data tersebut adalah item_no. Komponen value adalah qty_sales.

$\sqrt{0+0+4+4+1}=\sqrt{9}=3$

$\operatorname{sim}(100808,100807)=\frac{8}{(3,74165 * 3)}=0,712698$

Nilai similarity produk 100808, 100809

C. $\mathrm{D}=(1 * 0)+(1 * 0)+(0 * 1)+(2 * 0)+(2 *$

$0)+(2 * 1)+(0 * 1)=0+0+0+0+0+2+$ $0=2$
Data training dan data testing akan ditransformasi menjadi matriks item - user menggunakan pivot tabel. Matriks item - user yang berasal dari data training memiliki 346 baris dan 169 kolom yang diperihatkan pada Tabel 1. Matriks item - user yang berasal dari data testing memiliki 134 baris dan 103 kolom yang diperlihatkan pada Tabel 1 dan Tabel 2.

Tabel 1. Sampel Matriks Item - User Data Training

\begin{tabular}{lccccc}
\hline Item_No & 100076 & 100109 & 100111 & 100156 & 100188 \\
\hline 100473 & 2 & 0 & 0 & 0 & 0 \\
102574 & 1 & 0 & 0 & 0 & 1 \\
102576 & 0 & 0 & 0 & 0 & 1 \\
102578 & 0 & 0 & 1 & 1 & 0 \\
102580 & 0 & 0 & 0 & 0 & 0 \\
102582 & 0 & 0 & 2 & 0 & 0 \\
& & & & & \\
\end{tabular}

Tabel 2. Sampel Matriks Item - User Data Testing

\begin{tabular}{lccccc}
\hline Item No & 100076 & 100608 & 100654 & 103862 & 103872 \\
\hline 100473 & 0 & 0 & 0 & 0 & 0 \\
100803 & 0 & 2 & 1 & 3 & 0 \\
100807 & 0 & 1 & 0 & 0 & 0 \\
100808 & 0 & 0 & 0 & 3 & 0 \\
102576 & 0 & 0 & 0 & 0 & 0 \\
102578 & 0 & 0 & 0 & 0 & 0 \\
\hline
\end{tabular}

3.3. Menghitung Similarity Antar Produk dengan

Menggunakan Algoritma Cosine similarity.

Data training dan data testing akan dihitung tingkat similarity antar produk menggunakan Cosine Similarity.

Selanjutnya menghitung tingkat similarity antar produk dengan memakai data training. Menggunakan beberapa contoh perhitungan diperoleh nilai sebagai berikut:
a. Nilai similarity produk 100808, 100807
C. $\mathrm{D}=(1 * 0)+(1 * 0)+(2 * 2)+(2 * 2)+(2 *$
$0)+(0 * 1)=0+0+4+4+0+0=8$
$|C|=\sqrt{1^{2}+1^{2}+2^{2}+2^{2}+2^{2}+0^{2}}=$

$$
\begin{aligned}
& \sqrt{1+1+4+4+4+0}=\sqrt{14}=3,74165 \\
& |D|=\sqrt{0^{2}+0^{2}+2^{2}+2^{2}+0^{2}+1^{2}}=
\end{aligned}
$$

$|C|=\sqrt{1^{2}+1^{2}+2^{2}+2^{2}+2^{2}+0^{2}}=$
$\sqrt{1+1+4+4+4+0}=\sqrt{14}=3,74165$
$|D|=\sqrt{0^{2}+0^{2}+1^{2}+0^{2}+0^{2}+1^{2}+1^{2}}=$
$\sqrt{0+0+1+0+0+1+1}=\sqrt{3}=1,73205$

Jurnal Informasi dan Teknologi Vol . 3 No. 4 (2021) 202-208 
$\operatorname{sim}(100808,100809)=\frac{2}{(3,74165 * 1,73205)}=0,308607$

b. Nilai similarity produk 100808, 100804

C. $\mathrm{D}=(0 * 4)+(1 * 2)+(1 * 0)+(2 * 2)+(2 *$

$0)+(2 * 0)+(0 * 3)=0+2+0+4+0+0+$

$0=6$

$|C|=\sqrt{1^{2}+1^{2}+2^{2}+2^{2}+2^{2}+0^{2}}=$

$\sqrt{1+1+4+4+4+0}=\sqrt{14}=3,74165$

$|\mathrm{D}|=\sqrt{4^{2}+2^{2}+0^{2}+2^{2}+0^{2}+0^{2}+3^{2}}=$ $\sqrt{16+4+0+4+0+0+9}=\sqrt{33}=5,77456$

$\operatorname{sim}(100808,100804)=\frac{6}{(3,74165 * 5,77456)}=0,279145$

c. Nilai similarity produk 100804, 100807

C. $\mathrm{D}=(4 * 0)+(2 * 0)+(2 * 2)+(0 * 2)+(3 *$

1) $=0+0+4+0+3=7$

$|C|=\sqrt{4^{2}+2^{2}+2^{2}+0^{2}+3^{2}}=$

$\sqrt{16+4+4+0+9}=\sqrt{33}=5,77456$

$|\mathrm{D}|=\sqrt{0^{2}+0^{2}+2^{2}+2^{2}+1^{2}}=$

$\sqrt{0+0+4+4+1}=\sqrt{9}=3$

$\operatorname{sim}(100804,100807)=\frac{7}{(5,77456 * 3)}=0,40$

d. Nilai similarity produk 100804, 100809

C. $\mathrm{D}=(4 * 0)+(2 * 0)+(0 * 1)+(2 * 0)+(0 *$

1) $+(3 * 0)+(0 * 1)=0+0+0+0+0+0+$ $0=0$

$\operatorname{sim}(100804,100809)=0$

e. Nilai similarity produk 100807, 100809

C. $\mathrm{D}=(0 * 1)+(2 * 0)+(2 * 0)+(0 * 1)+(1 *$ $0)+(0 * 1)=0+0+0+0+0+0=0$ $\operatorname{sim}(100807,100809)=0$

3.4. Membuat Matriks Similarity Antar Produk.

Setelah menghitung nilai similarity antar produk,
selanjutnya akan dibuat matriks item - item. Matriks in bertujuan untuk melihat hubungan dan kemiripan antar 2 produk. Data training matrik item - item memiliki 346 baris dan 346 kolom Data testing matriks item item memiliki 134 baris dan 134 kolom. Berdasarkan perhitungan similarity antar produk, maka matriks similarity pada data training dapat dilihat pada Tabel 3.

Tabel 3. Sampel Matriks Similarity Antar Produk Data Training

\begin{tabular}{lrrrr}
\hline Item_no & 100804 & 100807 & 100808 & 100809 \\
\hline 100804 & 1 & 0,4 & 0,279145 & 0 \\
100807 & 0,4 & 1 & 0,712698 & 0 \\
100808 & 0,279145 & 0,712698 & 1 & 0,308607 \\
100809 & 0 & 0 & 0,3086070 & 1 \\
\hline
\end{tabular}

Tabel 3 memperlihatkan beberapa perhitungan Total similarity antar produk. Produk 100804 memiliki tingkat kemiripan dengan produk 100807 sebesar 0,4, produk 100807 memiliki tingkat kemiripan dengan produk 10808 sebesar 0,712698.

\subsection{Menghitung Prediksi Score Produk dan Error per} Pelanggan.

Perhitungan score produk dengan memakai rumus Weighted Sum dan tingkat error dengan rumus Root Mean Squared Error dalam memberikan rekomendasi kepada pelanggan. Perhitungan nilai score untuk masing - masing pelanggan dilakukan dengan menghitung tingkat similarity dari produk yang dipilih oleh pelanggan dengan produk histori data penjualan. Selanjutnya, nilai similarity terebut akan dikalikan dengan qty_sales dan ditotalkan. Kemudian, akan dibagi dengan total dari nilai similarity dari produk histori data penjualan. Berikut beberapa perhitungan score dan error untuk pelanggan 100654 data training.

a. Nilai prediksi score dan error pelanggan 100654 terhadap produk 100808 yang disajikan pada Tabel 4.

Tabel 4. Score dan Error Pelanggan 100654 Terhadap Produk 100808

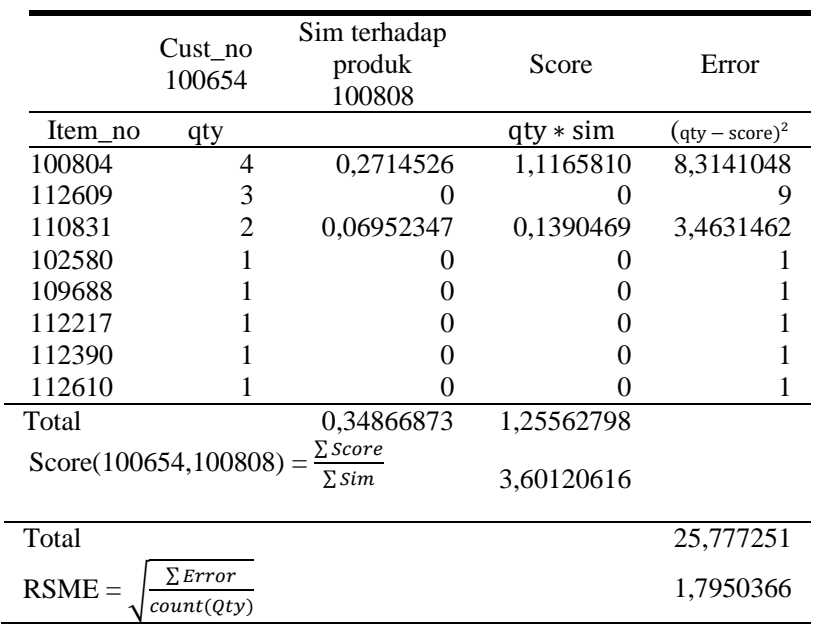

b. Nilai prediksi score dan error pelanggan 100654 terhadap produk 103082 disajikan pada Tabel 5.

Tabel 5 Score dan Error Pelanggan 100654 Terhadap Produk 103082

\begin{tabular}{cccc}
\hline Cust_no & $\begin{array}{c}\text { Sim terhadap } \\
\text { produk }\end{array}$ & Score & Error \\
100654 & 103082 & & \\
& & \\
\hline
\end{tabular}

\begin{tabular}{crrrr}
\hline $\begin{array}{c}\text { Item_ } \\
\text { no }\end{array}$ & qty & & qty $* \operatorname{sim}$ & $(\text { qty }- \text { score })^{2}$ \\
\hline 100804 & 4 & 0,348155311 & 1,39262124 & 6,7984239 \\
112609 & 3 & 0 & 0 & 9 \\
110831 & 2 & 0 & 0 & 1 \\
102580 & 1 & 0 & 0 & 1 \\
109688 & 1 & 0 & 0 & 1 \\
112217 & 1 & 0 & 0 & 1 \\
112390 & 1 & 0 & 0 & 1 \\
112610 & 1 & 0 & 0 & 1 \\
\hline
\end{tabular}

\begin{tabular}{lll}
\hline Total & 0,3481553311 & 1,39262124
\end{tabular}

Score $(100654,103082)=\frac{\sum \text { Score }}{\sum \text { Sim }}$ 
3.6. Memberikan Hasil Rekomendasi Produk kepada Pelanggan.

Dalam memberikan rekomendasi produk kepada pelanggan dilakukan dengan menghitung nilai score produk untuk pelanggan tertentu. Rekomendasi yang diberikan kepada pelanggan tersebut adalah 10 produk teratas. Nilai score yang dipakai dalam rekomendasi ini adalah nilai score 10 produk tertinggi. Produk - produk yang dijadikan rekomendasi kepada pelanggan, antara 1 pelanggan dengan pelanggan lain tidaklah sama. Rekomendasi produk kepada pelanggan 100654 dengan memakai data training dapat dilihat pada Tabel 6.

Tabel 6. 10 Rekomendasi Produk kepada Pelanggan 100654

\begin{tabular}{rrrl}
\hline \multicolumn{1}{c}{ Score } & RSME & Item_no & \multicolumn{1}{c}{ Item_name } \\
\hline 4 & 1,7606 & 103082 & PLAT SS 04X1X2 \\
4 & 1,7190 & 100807 & CANANG MDF KODE 6 \\
4 & 1,9765 & 100811 & CANANG PARTICLE \\
3,715209 & 1,7280 & 100805 & CAARD KODE \\
3,614710 & 1,7510 & 103057 & PLAT AL 04X1X2 \\
3,601206 & 1,7950 & 100808 & CANANG MDF KODE 9 \\
3 & 1,8660 & 120240 & TRIPLEX MICA OKE 3 DOF \\
3 & 1,8660 & 112167 & CARTA HPL 1727 T \\
3 & 1,8660 & 111511 & CELIGHT LINEN \\
& & & BLUE HPL 0248 T STAIN \\
3 & 1,8660 & 116945 & EWIGE LEBEN LEM KACA \\
& & & STD WHITE \\
\hline
\end{tabular}

Rekomendasi produk menggunakan Machine Learning untuk pelanggan 100654 dengan menggunakan data training dapat dilihat pada Gambar 3 .

get_recommendation_Training(100654)
100654

\begin{tabular}{rrrrr}
\multicolumn{2}{c}{ predicted } & error_rsme & item_no & item_name \\
\hline 0 & 4.000000 & 1.760626 & 103082 & PLAT SS 04X1X2 \\
1 & 4.000000 & 1.719082 & 100807 & CANANG MDF KODE 6 \\
2 & 4.000000 & 1.976509 & 100811 & CANANG PARTICLE BOARD KODE 15 \\
3 & 3.715209 & 1.728061 & 100805 & CANANG MDF KODE 18 \\
4 & 3.614710 & 1.751024 & 103057 & PLAT AL 04X1X2 \\
5 & 3.601206 & 1.795037 & 100808 & CANANG MDF KODE 9 \\
6 & 3.000000 & 1.866094 & 120240 & TRIPLEX MICA OKE 3 DOF \\
7 & 3.000000 & 1.866094 & 112167 & CARTAHPL 1727 T DELIGHT LINEN \\
8 & 3.000000 & 1.866094 & 111511 & CARTA HPL 0248 T STAIN BLUE \\
9 & 3.000000 & 1.866094 & 116945 & EWIGE LEBEN LEM KACA STD WHITE
\end{tabular}

Gambar 3. Rekomendasi Produk untuk Pelanggan 100654

Pada Gambar 3 dan Tabel 6 memperlihatkan perhitungan rekomendasi pada data training secara manual dan secara sistem memperlihatkan hasil yang sama. Rekomendasi produk kepada pelanggan 101230 dengan memakai data testing dapat dilihat pada Tabel 7 .
Tabel 7. 10 Rekomendasi Produk kepada Pelanggan 101230

\begin{tabular}{rrrl}
\hline \multicolumn{1}{c}{ Score } & RSME & Item_no & \multicolumn{1}{c}{ Item_name } \\
\hline 3 & 1,3380 & 111546 & CARTA HPL 0298 F CLEAR \\
3 & 1,3710 & 117166 & WHITE \\
3 & 1,2310 & 110493 & KSOCK PIPA AS BU 18 U \\
& & & METER \\
2 & 1,4832 & 110159 & KLASSEN FW.9120 REL \\
2 & 1,5433 & 116922 & LMR AS 380 \\
2 & 1,5129 & 109225 & HOTSUMINT 1 SISI 15 \\
1,828427 & 1,4342 & 110830 & TRIPLEX 9 IND TEMBAK F 30 \\
1,640754 & 1,3599 & 112609 & BLOCK BOARD AFR 15 \\
1 & 1,5743 & 103059 & PLAT AL 06X1X2 \\
1 & 1,5599 & 112396 & CARTA HPL 7876 T \\
& & &
\end{tabular}

Rekomendasi produk menggunakan Machine Learning untuk pelanggan 101230 dengan menggunakan data testing dapat dilihat pada Gambar 4.

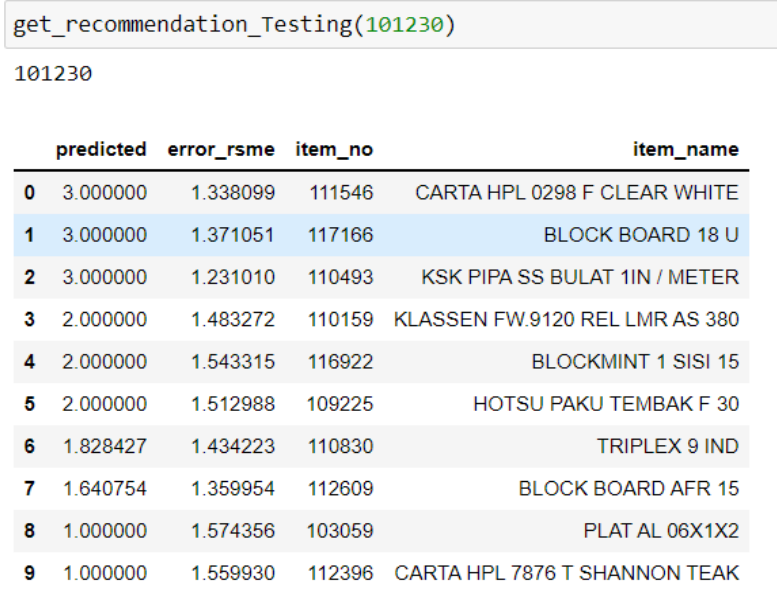

\begin{tabular}{rrrrr} 
& predicted & error_rsme & item_no & item_name \\
\hline $\mathbf{0}$ & 3.000000 & 1.338099 & 111546 & CARTA HPL 0298 F CLEAR WHITE \\
$\mathbf{1}$ & 3.000000 & 1.371051 & 117166 & BLOCK BOARD 18 U \\
$\mathbf{2}$ & 3.000000 & 1.231010 & 110493 & KSK PIPA SS BULAT 1IN / METER \\
$\mathbf{3}$ & 2.000000 & 1.483272 & 110159 & KLASSEN FW.9120 REL LMR AS 380 \\
$\mathbf{4}$ & 2.000000 & 1.543315 & 116922 & BLOCKIMINT 1 SISI 15 \\
$\mathbf{5}$ & 2.000000 & 1.512988 & 109225 & HOTSU PAKU TEMBAK F 30 \\
$\mathbf{6}$ & 1.828427 & 1.434223 & 110830 & TRIPLEX 9 IND \\
$\mathbf{7}$ & 1.640754 & 1.359954 & 112609 & BLOCK BOARD AFR 15 \\
$\mathbf{8}$ & 1.000000 & 1.574356 & 103059 & PLAT AL 06X1X2 \\
$\mathbf{9}$ & 1.000000 & 1.559930 & 112396 & CARTA HPL 7876 T SHANNON TEAK
\end{tabular}

Gambar 4. Rekomendasi Produk untuk Pelanggan 101230

Pada gambar 4 dan Tabel 7 memperlihatkan perhitungan rekomendasi pada data testing secara manual dan secara sistem memperlihatkan hasil yang sama.

\section{Kesimpulan}

Berdasarkan hasil dan pembahasan dapat disimpulkan bahwa metode Item-based Collaborative Filtering dapat digunakan dalam memberikan rekomendasi produk kepada pelanggan, Cosine Similarity memberikan hasil yang baik dalam menghitung tingkat kemiripan antar produk, dan metode ini dapat menjadi referensi dan acuan perusahaan dalam memberikan rekomendasi kepada pelanggan.

\section{Daftar Rujukan}

[1] Sharon, Defit, S., \& Nurcahyo, G. W. (2021). Tingkat Efisiensi Penggunaan Resep Dokter Spesialis Menggunakan Metode K-Means Clustering. Jurnal Informasi Dan Teknologi, 121-127. https://doi.org/10.37034/jidt.v3i3.118

[2] Jan Wira Gotama Putra, 2020. Pengenalan Konsep Pembelajaran Mesin dan Deep Learning, Tokyo. 
[3] Islamiyah, M., Subekti, P., \& Andini, T. D. (2019). Utilization of CollaboratPemanfaatan Metode Based Collaborative Filtering Untuk Rekomendasi Wisata Di Kabupaten Malangive Filtering Method for Tourism Recommendations in Malang Regency. Jurnal Ilmiah Teknologi Informasi Asia, 13(2), 143. https://doi.org/10.32815/jitika.v13i2.70

[4] Setiawan, Y., Nurwanto, A., \& Erlansari, A. (2019). Implementasi Item Based Collaborative Filtering Dalam Pemberian Rekomendasi Agenda Wisata Berbasis Android. Pseudocode, $6(1)$,

13-20. https://doi.org/10.33369/pseudocode.6.1.13-20

[5] Ramzan, B., Bajwa, I. S., Jamil, N., Amin, R. U., Ramzan, S., Mirza, F., \& Sarwar, N. (2019). An Intelligent Data Analysis for Recommendation Systems Using Machine Learning. Scientific Programming, 2019 , https://doi.org/10.1155/2019/5941096

[6] Jepriana I. W., Hanief S, (2020). Analisis dan Implementasi Metode Item- Based Collaborative Filtering Untuk Sistem Rekomendasi Stmik Stikom Bali. Janapati, 9(2), 171-180. http://dx.doi.org/10.23887/janapati.v9i2.23218

[7] Prasetyo, B., Haryanto, H., Astuti, S., Astuti, E. Z., \& Rahayu, Y. (2019). Implementasi Metode Item-Based Collaborative Filtering dalam Pemberian Rekomendasi Calon Pembeli Aksesoris Smartphone. Eksplora Informatika, 9(1), 17-27. https://doi.org/10.30864/eksplora.v9i1.244

[8] Putra, A. I., \& Santika, R. R. (2020). Implementasi Machine Learning dalam Penentuan Rekomendasi Musik dengan Metode Content-Based Filtering. Edumatic: Jurnal Pendidikan Informatika, 4(1), 121-130. https://doi.org/10.29408/edumatic.v4i1.2162

[9] Feng, J., Fengs, X., Zhang, N., \& Peng, J. (2018). An improved collaborative filtering method based on similarity. PLOS ONE, 13(9), e0204003. https://doi.org/10.1371/journal.pone.0204003

[10] Kouadria, A., Nouali, O., \& Al-Shamri, M. Y. H. (2019). A Multi-criteria Collaborative Filtering Recommender System Using Learning-to-Rank and Rank Aggregation. Arabian Journal for Science and Engineering, 45(4), 2835-2845. https://doi.org/10.1007/s13369-019-04180-3

[11]Rana, A., \& Deeba, K. (2019). Online Book Recommendation System using Collaborative Filtering (With Jaccard Similarity). Journal of Physics: Conference Series, 1362, 012130. https://doi.org/10.1088/1742-6596/1362/1/012130

[12]Kumar Ojha, R., \& Bhagirathi Nayak, D. (2018). Application of Machine Learning in Collaborative Filtering Recommender Systems. International Journal of Engineering \& Technology, 7(4.38), 213. https://doi.org/10.14419/ijet.v7i4.38.24445

[13]Lu, Q., \& Xia, J. (2019). Research on the Application of Itembased Collaborative Filtering Algorithms in MOOC. Journal of Physics: Conference Series, 1302, 032020. https://doi.org/10.1088/1742-6596/1302/3/032020

[14] Sinaga, A. S. R. (2020). Machine Learning Prediksi Karakter Pengguna Hastag (\#) Bahasa Generasi Milenial Di Sosial Media. Indonesian Journal of Applied Informatics, 4(2), 165. https://doi.org/10.20961/ijai.v4i2.41764

[15]Pambudi, H. K., Kusuma, P. G. A., Yulianti, F., \& Julian, K. A (2020). PREDIKSI STATUS PENGIRIMAN BARANG MENGGUNAKAN METODE MACHINE LEARNING. Jurnal Ilmiah Teknologi Infomasi Terapan, 6(2), 100-109. https://doi.org/10.33197/jitter.vol6.iss2.2020.396

[16]Sari, K. R., Suharso, W., \& Azhar, Y. (2020). Pembuatan Sistem Rekomendasi Film dengan Menggunakan Metode Item Based Collaborative Filtering pada Apache Mahout. Jurnal Repositor, 2(6), 767. https://doi.org/10.22219/repositor.v2i6.936

[17]Wiputra, M. M., \& Shandi, Y. J. (2021). Perancangan Sistem Rekomendasi Menggunakan Metode Collaborative Filtering dengan Studi Kasus Perancangan Website Rekomendasi Film. Media Informatika, 20(1), $1-18$. https://doi.org/10.37595/mediainfo.v20i1.54

[18] Jaja, V. L., Susanto, B., \& Sasongko, L. R. (2020). Penerapan Metode Item-Based Collaborative Filtering Untuk Sistem Rekomendasi Data MovieLens. d'CARTESIAN, 9(2), 78. https://doi.org/10.35799/dc.9.2.2020.28274 